\title{
Implementation of the Cash-Intensive Program from the Village Fund in Overcoming Poverty in the Karang Gading Village Community, Labuhan Deli District, Deli Serdang Regency
}

\author{
Hajar Risa ${ }^{1}$, Badaruddin ${ }^{2}$, Munir Tanjung ${ }^{3}$ \\ ${ }^{1,2,3}$ Universitas Sumatera Utara, Indonesia \\ Corresponding Author: Munir Tanjung
}

\begin{abstract}
The cash-intensive program is a community empowerment activity derived from village fund sourced from the state budget (APBN) with the target of poor families being productive by utilizing appropriate resources and technology in overcoming poverty, increasing income, and reducing stunting rates, through selfmanagement, and prioritizing local labor and materials. Karang Gading Village as the object of research, because it is the village with the largest poor population in Deli Serdang Regency. The research approach uses a qualitative descriptive approach. Determination of informants using purposive sampling. Data collection techniques using observation, interviews, and documentation. The data analysis technique used descriptive qualitative data analysis, including data reduction, data display, conclusion drawing and verification. The findings of the study are the implementation of the cash-intensive program in Karang Gading Village when viewed from four aspects according to Edwards III's theory on the concrete rebate activities for landfilling sirtu in Hamlet VI for the 2020 fiscal year the results have not been maximized, communication has not been fully conveyed, the resources are not sufficient, the bureaucratic structure is not well organized and only from the aspect of disposition or attitude that is sufficient so that the desired goals have not been achieved. The supporting factors for the cash-intensive program include: Deli Serdang Regency Government policies with the Regent's Regulation and the inhibiting factors for the
\end{abstract}

cash-intensive program include: the interest of the people of Karang Gading Village and the expertise of workers. The impact of the implementation of the cash-intensive program on poverty in Karang Gading Village, Labuhan Deli District, Deli Serdang Regency is that it has not been able overcoming poverty rate in Karang Gading Village because it is only temporary to support the daily needs of wage earners.

Keywords: Cash-Intensive Program, Village Fund, Overcoming Poverty

\section{INTRODUCTION}

The cash-intensive program is a community empowerment activity derived from village fund sourced from the state budget (APBN) with the target of poor families being productive by utilizing appropriate resources and technology in overcoming poverty, increasing income, and reducing stunting rates, through selfmanagement, and prioritizing local labor and materials.

Kislat and Menkhoff (2011), explained that the village fund program in Thailand is one of the largest microfinance programs in the world aimed at increasing access to finance and income in rural areas. Previous research has shown that this program has succeeded in realizing its ambitions to some degree. We extend this work by analyzing the second wave of households and find that village funds for 
community borrowers are characterized by low economic status, as the purpose of village funds loans is for their household lifeline. However, we cannot identify significant substitutions between village fund loans and other loans.

The use of village funds is prioritized for physical or infrastructure development and village community empowerment programs. The village fund was disbursed starting from 2015 to 2020 data that were successfully summarized by the village facilitator which was recapitulated by the Ministry of Villages, Development of Disadvantaged Regions and Transmigration.

Until now, the Government and Regional Governments in Indonesia are still facing the problem of poverty that is multidimensional. Poverty is the cause and effect of a vicious cycle - a series of problems of unemployment, the low quality of Indonesian human resources, and the low level of community welfare. This condition is illustrated by the high number of poor people and the number of open unemployment, as well as the low human development index (HDI) of Indonesia compared to the majority of other countries. The quality of human resources is indicated by the HDI. The human development index is a composite indicator of health status as seen from life expectancy at birth, education level as measured by the adult literacy rate and the combined gross enrollment rate for primary, secondary, higher education, and the economic level of the population as measured by gross domestic product. (GDP) per capita with purchasing power parity.

The problem of poverty is also experienced by Deli Serdang Regency, which consists of 22 (twenty two) subdistricts, 380 (three hundred and eighty) villages and 14 (fourteen) sub-districts with a population of 2,114,627 people and an area of 2,238,353 km2. Deli Serdang Regency has a poor population of $4.13 \%$ in 2019 according to data from the Central Statistics Agency for Deli Serdang Regency, of course this is a difficult task for the Deli
Serdang Regency Government to reduce the number of poor people every year.

It was recorded at the Department of Community and Village Empowerment of Deli Serdang Regency that the largest amount of village funds for 2020 was obtained by Karang Gading Village, Labuhan Deli District, because the largest poor population in Deli Serdang Regency was in that village.

In implementing the cash-intensive program policy, it is necessary to first understand the definition of Policy Implementation. The approach used in analyzing the implementation of policies on energy conservation is the theory put forward by George C. Edwards III. Where implementation can start from abstract conditions and a question about whether the conditions for policy implementation can be successful, according to George C. Edwards III there are four variables in public policies, namely Communications, resources, dispositions or attitudes and bureaucratic structure.

The success of implementation according to Merilee S. Grindle in Agustino (2008:154) is influenced by two major variables, namely the content of the policy and the implementation environment.

1. The extent to which the interests of the group or target groups are contained in the content of the policy.

2. Types of benefits received by the target groups.

3. The extent to which the desired change of the policy.

4. Is the location of a program correct?

5. Whether a policy has mentioned the implementor in detail.

6. Is a program supported by adequate resources.

Regarding various factors in policy implementation, Wibawa (1994:39) provides an overview in the form of a chart on the determinants of policy implementation performance. It is explained that there are 4 (four) interacting factors that focus on policy performance, these factors are: 
1. Fill in the policy.

2. Political will.

3. Characteristics of the target group.

4. Environmental support.

According to Supriatna (1997:90) states that "poverty is a completely limited situation that occurs not according to the will of the person concerned". The community can be categorized as a poor community if it is characterized by low levels of education, income, work productivity, health and nutrition and the welfare of their lives are shows a circle of powerlessness. Poverty can also be caused by limited human resources, where through formal and non-formal education channels eventually lead to consequences for the low level of informal education.

According to Kuncoro (1997:131) the population of this country is poor because they depend on the subsystem agricultural sector, traditional production methods, which are often accompanied by apathy towards the environment. The causes of poverty from an economic point of view are: First, on a micro basis, poverty arises because of the unequal pattern of resource ownership which causes an unequal distribution of income.

Soetrisno (1990:2-3), describes that the emergence of poverty is related to the culture that lives in society, injustice in the ownership of production factors and the use of the development approach model adopted by a country.

Meanwhile, Chambers (1983:149) asserts that the factors causing poverty are the entanglement of poverty or loss of rights. Wealth that is difficult to return, may be due to the need for pressure that exceeds the threshold of its strength, for example expenses that have been calculated previously, but the amount is very large, or suddenly faced with a severe crisis.

\section{RESEARCH METHODS}

The research approach uses a qualitative descriptive approach, which according to Nazir (1988) descriptive method is a method in examining the status of a group of people, an object, condition, itera of thought or class of events in the present, while according to Sugiyono (2005) states that descriptive method is a method used to describe or analyze a research result but is not used to make broader conclusions. Meanwhile, according to Whitney (1960), the descriptive method is a fact-finding with the right interpretation.

Determination of informants using purposive sampling. As Research Informants in this study are as follows:

1. Labuhan Deli sub-district head is 1 person

2. Head of Karang Gading Village is 1 person

3. Head of BPD Karang Gading Village is 1 person

4. Treasurer of Karang Gading Village is 1 person

5. Village cash-intensive wage recipients is 3 people

6. Community Leader of Karang Gading Village is 1 person

Data collection techniques using observation, interviews, and documentation. In terms of data collection techniques carried out by researchers to meet the needs of primary data is through direct interviews. This type of interview is an in-depth interview with the use of verbal research tools. As for the secondary data collection technique, the researcher will conduct a literature study on literature, documents, other scientific writings and similar research studies that the researcher examines. The researcher will also classify the information obtained according to the needs, the division that the researcher makes aims to make it easier to find the data to be obtained.

The data analysis technique used descriptive qualitative data analysis, including data reduction, data display, conclusion drawing and verification.

\section{RESULT}

\section{Deli Serdang Regency Profile}

Astronomically, North Sumatra Province is in the western part of Indonesia, located on the lines 10 - 40 North Latitude 
and $980-1000$ East Longitude. This province is bordered by waters and seas as well as two other provinces: to the north it is bordered by the province of Aceh, to the east by the State of Malaysia in the Malacca Strait, to the south by the provinces of Riau and West Sumatra, and to the west by the Indian Ocean. Geographically, Deli Serdang Regency is located at $2^{\circ} 57^{\prime}$ North Latitude to $3^{\circ} 16^{\prime}$ North Latitude and $98^{\circ} 33^{\prime}$ East Longitude to $99^{\circ} 27^{\prime}$ East Longitude. Deli Serdang Regency has an area of 2,497.72 $\mathrm{km} 2$. The area is bordered in the north by Langkat Regency and the Malacca Strait, in the east by Serdang Bedagai Regency, in the south by Karo Regency and Simalungun Regency and in the west by Langkat Regency, Karo Regency, and Binjai City. Deli Serdang Regency is an area with a tropical climate with two seasons, namely the rainy season and the dry season. The rainy season and dry season are usually marked by the number of rainy days in each month of the season. Deli Serdang Regency consists of 22 sub-districts and 394 villages/kelurahan. These sub-districts include Gunung Meriah, Sinembah Tanjung Muda Hulu, Sibolangit, Kutalimbaru, Pancur Batu, Namorambe, Biru-Biru, Sinembah Tanjung Muda Hilir, Bangun Purba, Galang, Tanjung Morawa, Patumbak, Deli Tua, Sunggal, Hamparan Perak, Labuhan Deli, Percut Sei Tuan, Batang Kuis, Pantai Labu, Beringin, Lubuk Pakam, dan Pagar Merbau.

\section{Geographical Condition of Karang Gading Village}

Karang Gading Village was formed in 1965 with a population of 6,072 people and an area of 6,250 ha, located at the coordinates of 99,345161 east longitude and $1,609,583$ north latitude, most of the residents in Karang Gading Village work as fishermen.

The location of Karang Gading Village is bordered by:

a. North side: Pantai GadingVillage and the Strait of Malacca

b. South side: Telaga Tujuh Village c. East: Pantai GadingVillage

d. West: Paluh KurauVillage Desa

\section{Karang Gading Village Government Condition}

Karang Gading Village consists of 15 hamlets spread throughout the village area, while the IDM status of the village it bears is an underdeveloped village with a classification as a Swakarya Village in terms of population and area. The Village Government apparatus consists of 1 Village Head, 1 Village Secretary, 3 Section Heads and 3 Heads of Affairs and 15 Hamlet Heads. The following is data from the Karang Gading Village Government Apparatus, Labuhan Deli District, Deli Serdang Regency.

\section{Revenue and Expenditure Budget for Karang Gading Village, Labuhan Deli District, Deli Serdang Regency for Fiscal Year 2020}

In 2020, Karang Gading Village experienced a decline in transfer income, both Village Funds sourced from the APBN, as well as village fund allocations (ADD) and regional tax and levy revenue sharing (BHP) originating from the Deli Serdang Regency APBD as a result of the national budget allocation. and regions for handling and tackling COVID-19 which is currently endemic.

Based on the Regulation of the Minister of Villages, Development of Disadvantaged Regions, and Transmigration number 11 of 2019 concerning priorities for the use of village funds in 2020 as amended several times, the last time was the Regulation of the Minister of Villages, Development of Disadvantaged Regions, and Transmigration Number 14 of 2020 concerning the second amendment to the Regulation Minister of Villages, Development of Disadvantaged Regions, and Transmigration of the Republic of Indonesia Number 11 of 2019 concerning priority for use of village funds in 2020 that Village Funds for the 2020 fiscal year are prioritized for: 
1. Village cash assistance (BLT).

2. Countermeasures and prevention of COVID-19.

3. Physical work-intensive village cash.

Based on the Karang Gading Village APBN 2020 data, it can be calculated that the allocation for infrastructure work is $11.4 \%$ of the total Village Fund, while for BLT Desa $74.9 \%$ and $13.7 \%$ are allocated for stunting prevention activities, incentives for health cadres, PAUD teachers and other empowerment activities.

\section{Implementation of the Cash-Intensive Program Policy in Karang Gading Village, Labuhan Deli District, Deli Serdang Regency for Fiscal Year 2020}

Van Meter and Van Horn said state the implementation of public policy as actions taken by individuals or government and private groups directed to achieve the goals that have been set in previous policy decisions. Which means that the implementation process will not be carried out until the law or regulation is enacted and funds are provided to finance the process of implementing the policy. On the other hand, policy implementation is considered as a complex phenomenon that may be understood as a process, output or as a result. In the public policy implementation model, there are several policy implementation models, one of which was introduced by Edward III in 1980. To examine policy implementation, Edward started by asking two basic questions, namely:

1. What factors support the success of policy implementation?

2. What factors hinder the success of policy implementation?

From these two questions, Edward III's implementation model is formulated which has four variables, these variables that will affect the success or failure of policy implementation. The four variables in question are: communication, resources, dispositions and bureaucratic structure.

The findings of the study are the implementation of the cash-intensive program in Karang Gading Village when viewed from four aspects according to Edwards III's theory on the concrete rebate activities for landfilling sirtu in Hamlet VI for the 2020 fiscal year the results have not been maximized, communication has not been fully conveyed, the resources are not sufficient, the bureaucratic structure is not well organized and only from the aspect of disposition or attitude that is sufficient so that the desired goals have not been achieved.

\section{Factors Affecting the Implementation of the Cash-Intensive Program in Karang Gading Village, Labuhan Deli District, Deli Serdang Regency}

The supporting factors for the cashintensive program include: Deli Serdang Regency Government policies with the Regent's Regulation.

1. Joint Decree of the Minister of Home Affairs, Minister of Finance, Minister of Village, Development of Disadvantaged Regions and Transmigration and Minister of National Development Planning/Head of National Development Planning Agency Number: 140-8698 of 2017, Number:954/KMK.07/2017, Number:116 of 2017, Number:01/ SKB/M.PPN/12/2017 concerning Alignment and Strengthening of Policies to Accelerate the Implementation of Law Number 6 of 2014 concerning Villages.

2. Regulation of the Minister of Villages, Development of Disadvantaged Regions, and Transmigration Number 11 of 2019 concerning Priorities for the Use of Village Funds in 2020 as amended several times, most recently by Regulation of the Minister of Villages, Development of Disadvantaged Regions, and Transmigration Number 14 of 2020 concerning the second amendment to Regulation of the Minister of Villages, Development of Disadvantaged Regions, and Transmigration of the Republic of Indonesia Number 11 of 2019 
concerning Priorities for the Use of Village Funds in 2020 that Village Funds for the 2020 fiscal year are prioritized for:

a. Village cash assistance (BLT).

b. Countermeasures and prevention of COVID-19.

c. Physical work-intensive village cash.

3. Deli Serdang Regent Regulation Number 37 of 2020 concerning Procedures for Distribution and Determination of Details of Village Funds for Each Village in Deli Serdang Regency for Fiscal Year 2020 as a derivative of the Regulation of the Minister of Villages, Development of Disadvantaged Regions, and Transmigration Number 11 of 2019 concerning Priorities for the Use of Village Funds Year 2020 to be implemented in all villages in Deli Serdang Regency. Through the CCP policy, the Government seeks to provide job opportunities for marginal groups to participate in the implementation of development in order to obtain additional income to improve their lives. Through the 2018 Technical Guidelines for the Use of Village Funds for PKT, the Ministry of Villages, Development of Disadvantaged Regions, and Transmigration requires all villages as Village Fund recipients to carry out the PKT program, provided that the village:

a. Must allocate a minimum of $30 \%$ of the budget for development activities originating from the Village Fund Development Activities to pay labor wages.

b. Refocusing the use of the Village Fund portion in the amount of three to five development activities in accordance with the Regulation of the Minister of Villages, Development of Disadvantaged Regions, and Transmigration Number 19 of 2017 concerning Priority Determination of the Use of Village Funds.

c. Prioritizing marginalized people in labor recruitment including expert workers, assistant skilled workers, and workers from rural communities.

Inhibiting factors for the cash-intensive program include: the interest of the people of Karang Gading Village and the expertise of workers.

The factors that hinder this activity from being carried out in accordance with expectations are as follows:

1. Disposition/Attitude

The attitude of the Karang Gading Village Head as the person in charge of the cash-intensive program activity in the village who is less enthusiastic about implementing this program. implemented using the Village Cash Work Intensive pattern.

2. Human resources, namely skill/expertise of workers.

\section{Impact of the Village Cash-Intensive Program on Poverty in Karang Gading Village}

The impact of the implementation of the cash-intensive program on poverty in Karang Gading Village, Labuhan Deli District, Deli Serdang Regency is that it has not been able overcoming poverty rate in Karang Gading Village because it is only temporary to support the daily needs of wage earners.

Based on the circular issued by the Minister of Villages, Development of Disadvantaged Regions and Transmigration, there are 14 criteria that are used as indicators for the poor to receive village fund direct cash assistance (BLT), namely:

1. Floor area $<8 \mathrm{~m}^{2} /$ person.

2. Cheap earth/bamboo/wood floors.

3. Bamboo/thatch/cheap wood/wall without plaster.

4. Defecate without facilities/with other people.

5. Lighting without electricity.

6. Drinking water from wells/unprotected springs/rivers/rainwater.

7. Fuel wood/charcoal/kerosene.

8. Consumption of meat $/ \mathrm{milk} / \mathrm{chicken}$ only 1 time/week.

9. One set of clothes a year. 
10. Eat 1-2 times/day.

11. Unable to go to the puskesmas/polyclinic for treatment.

12. Sources of income for KK farmers with $500 \mathrm{~m}^{2}$ land, farm laborers, fisherman workers, construction workers, plantation workers, other jobs with wages of Rp600 thousand/month.

13. Education KK did not go to school/did not finish elementary school/graduated elementary school.

14. Do not have savings/easy to sell goods at least Rp500 thousand.

\section{CONCLUSION AND SUGGESTION}

The findings of the study are the implementation of the cash-intensive program in Karang Gading Village when viewed from four aspects according to Edwards III's theory on the concrete rebate activities for landfilling sirtu in Hamlet VI for the 2020 fiscal year the results have not been maximized, communication has not been fully conveyed, the resources are not sufficient, the bureaucratic structure is not well organized and only from the aspect of disposition or attitude that is sufficient so that the desired goals have not been achieved. The supporting factors for the cash-intensive program include: Deli Serdang Regency Government policies with the Regent's Regulation and the inhibiting factors for the cash-intensive program include: the interest of the people of Karang Gading Village and the expertise of workers. The impact of the implementation of the cash-intensive program on poverty in Karang Gading Village, Labuhan Deli District, Deli Serdang Regency is that it has not been able overcoming poverty rate in Karang Gading Village because it is only temporary to support the daily needs of wage earners.

From the conclusions above, as a consideration for the Village Government to make improvements to a better direction, the suggestions from the author are as follows:

1. It is recommended to the Deli Serdang Regency Community and Village
Empowerment Service to make a cashintensive program implementation competition with attractive prizes so that Village Heads are enthusiastic to implement this program.

2. It is recommended to the Deli Serdang Regency Community and Village Empowerment Service to provide more intensive assistance in the implementation of the Village Cash Intensive Program by creating a Mentoring Team determined by the Deli Serdang Regent's Decree in charge of assisting the process from beginning to end, monitoring and evaluating activities that.

3. It is recommended to the Village Head to make a commitment in the form of facts of integrity or a binding statement with the prospective recipients of the village cash work Intensive activity so that they can apply discipline in completing work in accordance with working people day (HOK) which has been stated in the RAB while maintaining quality the job.

4. It is recommended that the TPK involve a reliable handyman to supervise the work carried out by the workers while providing briefing and brief training related to the activities to be carried out.

5. It is recommended to the Village Head and TPK to select prospective recipients of wages for physical infrastructure activities with a cash-intensive pattern based on the integrated social welfare data (DTKS) issued by the Social Service of Deli Serdang Regency which is indeed a database of poor people who deserve government assistance so that this does not happen. conflict resulting from jealousy of villagers who have not been empowered to become wage recipients as a solution to the dilemma experienced by the village head.

\section{Acknowledgement: None}

Conflict of Interest: None 
Hajar Risa et.al. Implementation of the cash-intensive program from the village fund in overcoming poverty in the Karang Gading Village Community, Labuhan Deli District, Deli Serdang Regency.

\section{Source of Funding: None}

\section{REFERENCES}

1. Agustino, Leo. (2008). Dasar-dasar Kebijakan Publik. Bandung: Alfabeta.

2. Chambers, Robert. (1983). Pembangunan Desa Mulai dari Belakang. Jakarta: LP3ES.

3. Kislat, Carmen \& Menkhoff Lukas. (2011). The Village Fund Loan: Who Gets Keeps It and Loses It. Journal Departemen of Economics, Leibniz University Hannover, Konigsworther Platz 1, D-30167 Hannover.

4. Kuncoro, Mudrajad. (1997). Ekonomi Pembangunan Teori, Masalah dan Kebijakan, Yogyakarta: UPP-AMP YKPN.

5. Nazir. (1988). Metode Penelitian. Jakarta: Ghalia Indonesia.

6. Soetrisno. (1990). Metodologi Research. Jilid 3. Yogyakarta: Andi Offset.

7. Sugiyono. (2005). Metode Penelitian Kuantitatif dan Kualitatif dan R\&D, Bandung: Alfabeta.
8. Supriatna, Tjahya. (1997). Birokrasi Pemberdayaan dan Pengentasan Kemiskinan. Bandung: Humaniora Utama Press (HUP).

9. Whitney, F. L. (1960). The Elements of Resert Asian Eds. Osaka: Overseas Book Co.

10. Wibawa, Samodra. (1994). Kebijakan Publik: Proses dan Analisis. Cetakan Pertama. Jakarta: Intermedia.

How to cite this article: Risa $\mathrm{H}$, Badaruddin, Tanjung M. Implementation of the cashintensive program from the village fund in overcoming poverty in the Karang Gading Village Community, Labuhan Deli District, Deli Serdang Regency. International Journal of Research and Review. 2021; 8(6): 263-270. DOI: https://doi.org/10.52403/ijrr.20210632 